\title{
17. PETROGRAPHY AND STABLE OXYGEN AND CARBON ISOTOPE COMPOSITIONS OF CAMPANIAN GRAINSTONES AND RUDSTONES, NORTHEAST PROVIDENCE CHANNEL, BAHAMAS: ODP LEG 101, HOLE 634A ${ }^{1}$
}

\author{
W. R. McClain, ${ }^{2}$ R. P. Freeman-Lynde, ${ }^{2}$ and K. C. Lohmann ${ }^{3}$
}

\begin{abstract}
Petrographic descriptions and stable oxygen and carbon isotope compositions of microsamples of Campanian-age sediment gravity-flow deposits from Northeast Providence Channel, Bahamas, indicate deep-marine cementation of shallow-marine skeletal grains that were transported to the channel during the Late Cretaceous. Shallow-marine components are represented by mollusks, especially rudists, and shallow-water benthic foraminifers as well as sparse echinoderm and algal grains. The sole evidence of diagenesis in shallow-marine environments consists of micrite envelopes around skeletal grains. Shallow-marine skeletal grains have mean stable isotope values of $-3.1 \% 0 \delta^{18} \mathrm{O}$ and $+2.6 \%$ $\delta^{13} \mathrm{C}$. The $\delta^{18} \mathrm{O}$ values are consistent with precipitation in equilibrium with warm $\left(20^{\circ}-30^{\circ} \mathrm{C}\right)$, shallow-marine water. Deep-marine components are represented by equant calcite spar cements and rip-up clasts of slope sediments. Spar cements, exhibiting hexagonal morphology with scalenohedral terminations, most commonly occur as thin isopachous linings in the abundant porosity. Deep-marine cements have mean stable isotope values of $-1.1 \% 0 \delta^{18} \mathrm{O}$ and $+2.7 \%$ $\delta^{13} \mathrm{C}$. Deep-marine cements are ${ }^{18} \mathrm{O}$-enriched relative to shallow-marine skeletal grains, consistent with precipitation in equilibrium with colder $\left(10^{\circ}-20^{\circ} \mathrm{C}\right)$, deep-marine waters. The cement source during lithification appears to have been dissolution of aragonite and high-magnesium calcite skeletal grains, which made up part of the transported sediment. Interbedded periplatform ooze remains uncemented, or poorly cemented, probably because of lower permeability. Equant spar cements that occur in gravity-flow deposits recovered from Hole 634A have stable isotope compositions similar to spars in Lower and mid-Cretaceous shallow-water limestones exposed on the Bahama Escarpment, to Campanian-Paleocene deep-marine hardgrounds recovered during DSDP Leg 15 in the Caribbean, and to spars in AptianAlbian talus deposits at the base of the Campeche Escarpment recovered during DSDP Leg 77.
\end{abstract}

\section{INTRODUCTION}

Hole 634A, which was drilled in Northeast Providence Channel, Bahamas, during ODP Leg 101, penetrated a thick ( 300m) sequence of deep-water, sediment gravity-flow deposits of Campanian age from about 180 mbsf (meters below seafloor) to the base of the hole at 479 mbsf (Austin, Schlager, et al., 1986; Fig. 1). The Campanian section consists of grainstones and rudstones that contain abundant shallow-marine components (rudist and mollusk grains) and deep-marine components (equant spar and rip-up clasts of pelagic slope sediments), and less common lithoclasts of shallow-marine boundstones interbedded with periplatform chalk and ooze. Samples from Hole 634A (Table 1) offer an excellent opportunity to examine diagenesis of deepwater deposits containing shallow-marine components and to compare and contrast stable oxygen and carbon signatures of both shallow-marine and deep-marine diagenetic products within the Campanian section.

Determination of oxygen and carbon isotope compositions of microsamples has proved useful in previous diagenetic studies (Halley et al., 1984; Moldovanyi and Lohmann, 1984; Meyers and Lohmann, 1985; Moore, 1985; Prezbindowski, 1985; Woronick and Land, 1985; Freeman-Lynde et al., 1986). In particular, Freeman-Lynde et al. (1986) described medium to coarse equant spars in Lower and mid-Cretaceous shallow-bank limestones exposed on the Bahama Escarpment. These were interpreted to have precipitated from deep-marine water because they are isotopically heavier than the shallow-marine components in the limestones. In addition, Halley et al. (1984) described deep-

\footnotetext{
${ }^{1}$ Austin, J. A., Jr., Schlager, W., et al., 1988. Proc. ODP, Sci. Results, 101: College Station, TX (Ocean Drilling Program).

2 Department of Geology, University of Georgia, Athens, GA 30602 .
3 Department of Geological Sciences, University of Michigan, Ann Arbor, MI 48109
}

marine diagenesis of sediment gravity-flow deposits (AptianAlbian age) containing similar transported skeletal grains and equant spar from the base of Campeche Escarpment. However, this study did not resolve whether diagenesis occurred in water of marine, meteoric, or mixed composition.

This chapter presents analytical results of stable oxygen and carbon isotope studies of both shallow- and deep-marine components in Campanian grainstones and rudstones, as well as petrographic analyses of Campanian sediment gravity-flow deposits recovered at Hole 634A in Northeast Providence Channel. Oxygen isotopic compositions are distinctly different in shallow- and deep-marine components of these rocks, heavier $\delta^{18} \mathrm{O}$ values being characteristic of deep-marine components. Isotopic data and petrographic observations suggest that cementation of the shallow-marine components occurred at the seafloor or in the shallow subsurface from deep-marine water.

\section{GEOLOGICAL SETTING}

Northeast Providence Channel is one of several deep troughs that divide the Bahama and Florida platforms into individual carbonate banks (Fig. 1). The origin of these channels appears to involve block faulting, differential deposition, and erosion, although the relative contribution of each has not been determined adequately (Andrews et al., 1970; Paulus, 1972; Schlager et al., 1976; Mullins and Lynts, 1977; Austin, Schlager, et al., 1986). Mullins and Lynts (1977) suggested that these channels are fault-bounded and underlain by pelagic sediments. Paulus (1972) attributed the origin of the channels to the combination of slow sediment-accumulation rates in the channel (according to results from DSDP Site 98) and faster vertical reef growth along the walls. A mid-Cretaceous "megabank" was presumed to underlie the channels. Erosional processes are evidenced by scours, terraces, undercutting, and sediment removal in Tongue of the Ocean (Schlager et al., 1976). Several sites were occupied 


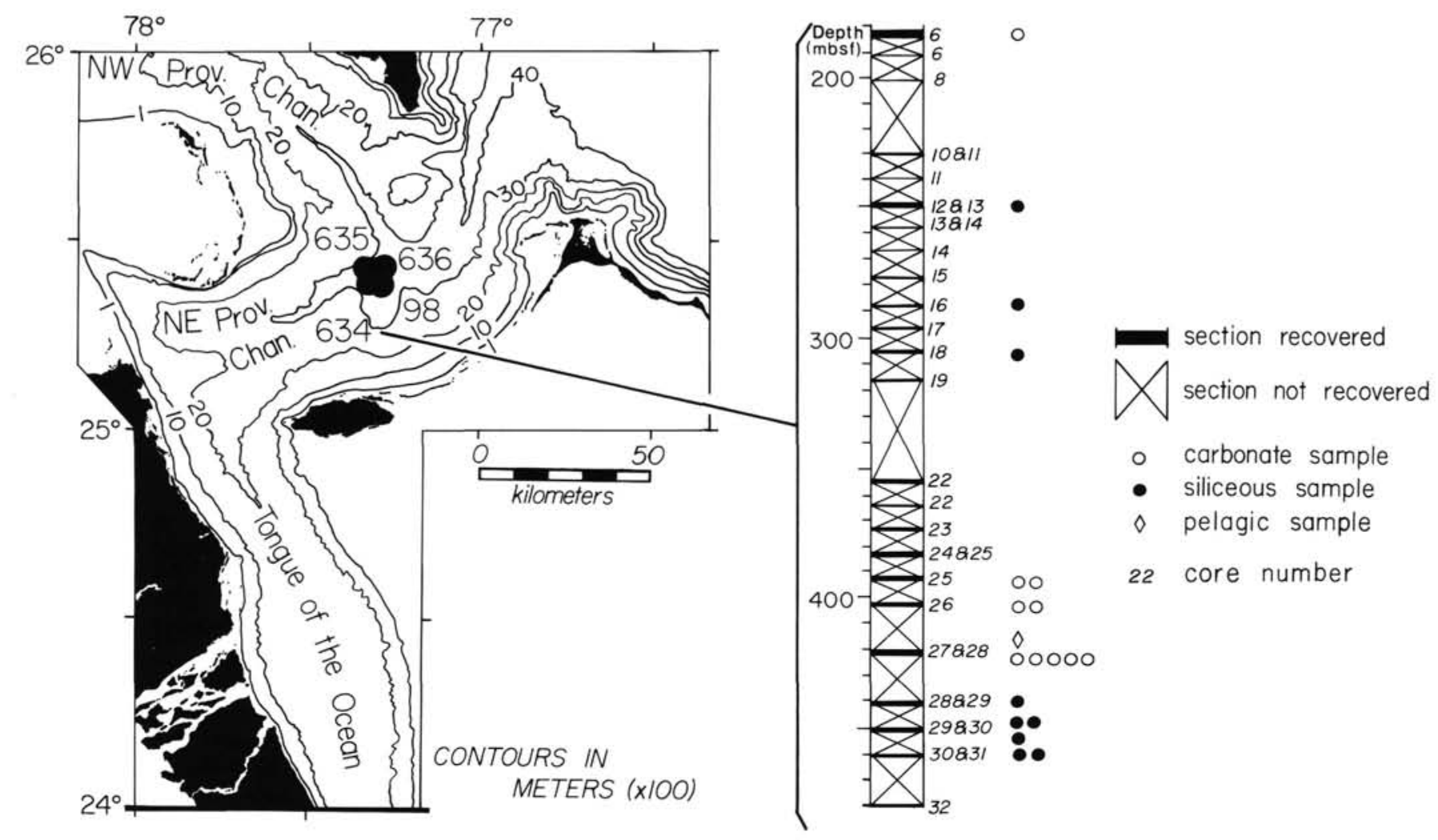

Figure 1. Location of DSDP Site 98 and ODP Sites 634, 635, and 636, Northeast Providence Channel, and summary of Campanian section penetrated at Hole 634A. Note poor recovery resulting from intercalation of unconsolidated periplatform chalk and ooze with lithified sediment gravityflow deposits. Bathymetry taken from Andrews et al. (1970) and Schlager et al. (1976).

Table 1. Sample analyses, Hole 634A.

\begin{tabular}{cll}
\hline Sample (interval in cm) & \multicolumn{1}{c}{ Rock type } & Analysis type \\
\hline 101-634A-6R-1, 11-13 & Rudstone & I, P \\
12R, CC, 1-3 & Silicified grainstone & P \\
16R, CC, 12-13 & Silicified rudstone & I, P \\
18R, CC, 1-4 & Silicified grainstone & P \\
25R, CC, 4-8 & Rudstone & I, P \\
25R, CC, 18-21 & Rudstone & I, P \\
26R, CC, 1-3 & Grainstone & P \\
26R, CC, 3-4 & Grainstone & P \\
$27 R, C C, 33-34$ & Pelagic mudstone & I, P \\
$28 R-1,70-72$ & Rudstone & I, P \\
28R-1, 81-84 & Rudstone & I, P \\
28R-1, 90-94 & Rudstone & I, P \\
28R-1, 105-109 & Grainstone & I, P \\
28R-1, 116-120 & Grainstone & P \\
29R-1, 51-52 & Silicified rudstone & I, P \\
29R, CC, 1-3 & Silicified rudstone & I, P \\
29R, CC, 10-12 & Silicified grainstone & P \\
30R-1, 23-24 & Silicified grainstone & I, P \\
31R-1, 33-37 & Silicified rudstone & I, P \\
31R-1, 38-41 & Silicified rudstone & I, P \\
\hline
\end{tabular}

${ }^{\mathrm{a}} \mathrm{I}=$ isotopic; $\mathrm{P}=$ petrographic.

during ODP Leg 101 to ascertain the origin of these channels by drilling to the presumed mid-Cretaceous "megabank" underlying the channels. These attempts to reach the "megabank" were unsuccessful, however, except at Site 627 (Austin, Schlager, et al., 1986).

Steep slopes in Northeast Providence Channel extend to depths exceeding $3000 \mathrm{~m}$ and normally receive pelagic sediments. Platform-margin environments supply sand- and gravel-sized, shallow-marine sediment to the channel by gravity flows result- ing from slumping and storm-generated currents across bank margins. Products of these periodic gravity flows, which occur between thick sequences of unconsolidated periplatform chalk and ooze in the deep basins, range in age from early Campanian to Holocene (Paulus, 1972; Schlager and Chermak, 1979; Mullins et al., 1980; Austin, Schlager, et al., 1986).

Hole 634A encountered a $\sim 300$-m-thick sequence of early Campanian-age sediment gravity-flow deposits and periplatform ooze between about 180 and 480 mbsf (Austin, Schlager, et al., 1986). High porosity throughout most of the section associated with periplatform chalk and ooze is indicated by downhole logging. Local intervals of siliceous deposits and spar-cemented sediment gravity-flow deposits occur in the section. DSDP Hole 98, which is less than $500 \mathrm{~m}$ from Hole $634 \mathrm{~A}$, encountered the upper part of this Campanian sequence and sampled similar deposits in the Tertiary (Paulus, 1972). Interbedded turbidites and periplatform ooze in the Quaternary have been recovered in numerous piston cores from the deep troughs of the Bahamas (Mullins and Neumann, 1979; Schlager and Chermak, 1979).

\section{METHODS}

Petrographic evaluation of Campanian grainstones from Hole 634A was accomplished using polished thin sections and a petrographic microscope. Scanning electron microscope (SEM) photomicrographs were obtained using a Philips 505 SEM at the University of Georgia. Samples were polished, acid-etched, and sputter-coated with gold-palladium. In addition, samples were sputter-coated with carbon and examined on the SEM in conjunction with EDAX to determine trace-element composition. Trace elements in these samples are generally below the limits of detection $(\sim 200 \mathrm{ppm})$.

Rudist and mollusk grains, spar cement, and micritic matrix of ripup clasts were microsampled for stable oxygen and carbon isotope analysis using a microdrilling assembly coupled to a binocular microscope. The $\delta^{18} \mathrm{O}$ and $\delta^{13} \mathrm{C}$ values were determined for microsampled compo- 
nents using a VG Micromass 602 E Ratio Mass Spectrometer at the University of Michigan. About $0.1 \mathrm{mg}$ of material was analyzed for each microsample. Microsamples were vacuum-roasted at $380^{\circ} \mathrm{C}$ to eliminate volatile organic contaminants and reacted with anhydrous phosphoric acid at $50^{\circ} \mathrm{C}$ in an on-line gas-extraction system coupled directly to the inlet of the mass spectrometer. Isotope ratios were measured relative to the University of Michigan Stable Isotope Laboratory standard gas (KIS-I), converted to PDB, and corrected for $\delta^{17} \mathrm{O}$ following the procedure of Craig (1957).

\section{SHALLOW-MARINE COMPONENTS}

\section{Petrography}

Shallow-marine components of the Campanian section at Hole 634A are skeletal grains in grainstones and rudstones, as well as boundstone lithoclasts from periplatform and perireef areas that were transported to the deep (1000-2000 m) Northeast Providence Channel by gravity flows. Skeletal grains in grainstones and rudstones were the only shallow-marine components analyzed during this study (Table 1).

Most skeletal grains consist of mollusk skeletal fragments, especially rudists, as well as shallow-water benthic foraminifers, including miliolids and peneropids, with sparse echinoderm and algal grains (Figs. 2-4). Some grains are well rounded, most likely reflecting abrasion in high-energy, shallow-marine environments, whereas others are angular, perhaps owing to breakage during transport to the deep-marine environment. The sole evidence of diagenesis in shallow-marine diagenetic environments for skeletal grains consists of micrite envelopes (5 to $40 \mu \mathrm{m}$ thick), which occur in samples throughout the section (Figs. 3, 4). Such micrite envelopes generally form by fungal and algal boring in shallow-marine environments (Bathurst, 1975). Although Hook et al. (1984) suggest that microbial boring can produce such envelopes in deep-marine water, micrite rims in our samples probably formed in shallow-marine environments. This conclusion is supported by the occurrence of micrite envelopes around grains in boundstone lithoclasts (which were lithified before transport), as well as around grains in grainstones and rudstones (the components of which were transported to deep-marine environments as individual particles). In addition, the intensity of deep-marine microbial boring decreases with increasing depth and is minimal at the estimated depths (1-2 km) at which our samples accumulated.

\section{Stable Oxygen and Carbon Isotope Compositions}

Moldovanyi and Lohmann (1984) and Meyers and Lohmann (1985) pointed out that an estimate of original isotopic composition of marine carbonate is a necessary starting point for discriminating progressive diagenetic processes because isotopic composition of marine carbonates has varied through time. Moldovanyi and Lohmann (1984) showed that rudist grains were useful for such estimates. Consequently, rudist and other mollusk grains from nine samples were analyzed to determine stable oxygen and carbon isotope compositions of shallow-marine components (Fig. 5; Tables 2 and 3). The $\delta^{18} \mathrm{O}$ values range from -2.2 to $-3.9 \%$ PDB, with a mean of $-3.1 \%$ PDB and standard deviation of $0.6 \%$ PDB. The $\delta^{13} \mathrm{C}$ values range from +1.9 to $+3.1 \%$ PDB, with a mean of $+2.6 \%$ PDB and standard deviation of $0.5 \%$ PDB. These $\delta^{18} \mathrm{O}$ values are consistent with precipitation in equilibrium with warm $\left(20^{\circ}-30^{\circ} \mathrm{C}\right)$, shallow-marine waters, assuming an ice-free world $\left(\delta^{18} \mathrm{O}_{\text {water }}=-1 \%\right.$ SMOW $)$. Similar stable isotope values were obtained for shallow-marine components (i.e., rudists, isopachous cements, and micrite matrix) in Lower and mid-Cretaceous strata exposed on the Bahama Escarpment (Freeman-Lynde et al., 1986) and from the subsurface of East Texas (Moldovanyi and Lohmann, 1984; Prezbindowski, 1985), although those from the Bahama Escarpment seem to be somewhat enriched in $\delta^{18} \mathrm{O}$ (Fig. 5).

\section{DEEP-MARINE COMPONENTS}

\section{Petrography}

Deep-marine components in Campanian grainstones and rudstones examined in this study are primarily cloudy, very fine to fine (10 to $30 \mu \mathrm{m})$ and clear, medium (75 to $200 \mu \mathrm{m})$ equant calcite spar (Figs. 3 and 4). Rip-up clasts of semiconsolidated to lithified deep-marine slope sediments also occur in several samples (Figs. 2 and 3). In addition, one sample appears to be an in-situ bed of lithified periplatform limestone, made up of micrite with intraparticle porosity from planktonic foraminifers. Numerous recovered intervals reveal varying degrees of deepmarine silicification. Some samples contain only silica cement surrounding calcitic grains; other samples consist entirely of silica, with complete replacement of skeletal grains. In fact, 9 of the 20 samples used in this study are from siliceous intervals (Figs. 1-3); their silica content is being studied separately.

Spar cement exhibits hexagonal morphology, and crystals have scalenohedral terminations, as determined by SEM and by handsample evaluation with a binocular microscope (Figs. 3 and 4). Cement occurs most commonly as thin, isopachous linings in abundant porosity. Porosity types in these samples include interparticle and intraparticle pores, vugs, and molds. Molds apparently resulted from deep-marine dissolution of aragonite and high-magnesium calcite skeletal grains, after transport to the deeper environment. Micrite rims (inferred to be shallow marine) surrounding molds are not fractured or broken, as might be expected if skeletal grains had been transported as hollow grains (that is, if dissolution had occurred before transport). Thus, skeletal grains were transported as solid grains with micrite rims, and subsequent dissolution left the micrite envelopes surrounding molds. Vugs probably formed on the deep seafloor as well. Very fine to fine spar commonly occurs in interparticle pores, but medium spar occurs mostly in vugs and molds. These cements are similar to those in Campeche talus recovered and analyzed for stable oxygen and carbon isotopic composition from DSDP Hole 536 (Halley et al., 1984).

Ten of the 11 carbonate samples were taken from a $100-\mathrm{m}$ interval (350-450 mbsf). Porosity (as estimated from thin-section petrography) ranges from about $2 \%$ to $20 \%$ in this group of samples, although most have porosities of $3 \%$ to $5 \%$. The remaining carbonate sample, taken from about 180 mbsf, has $20 \%$ porosity. Siliceous samples have essentially $0 \%$ porosity. Porosities, determined aboard ship by GRAPE and gravimetric and volumetric techniques, are $40 \%$ to $50 \%$ in beds above $250 \mathrm{mbsf}$ and $20 \%$ to $30 \%$ in beds below $250 \mathrm{mbsf}$. Compensated neutron and gamma-ray values from downhole logging indicate porosities between $40 \%$ and $75 \%$, providing evidence that the section is mostly uncemented except for the thin lithified intervals.

\section{Stable Oxygen and Carbon Isotope Compositions}

Stable oxygen and carbon isotope compositions were determined for 17 microsamples of clear, medium equant spar, cloudy, very fine to fine equant spar, and rip-up clasts taken from 13 samples (Fig. 6; Tables 2 and 4). Stable isotopic values of deepmarine components define a compositional field distinct from that defined for shallow-marine components. Although $\delta^{13} \mathrm{C}$ values are similar, $\delta^{18} \mathrm{O}$ values of deep-marine components are $1-2 \%$ PDB heavier than those of shallow-marine components. The $\delta^{18} \mathrm{O}$ values of deep-marine components are consistent with precipitation in equilibrium with colder $\left(10^{\circ}-20^{\circ} \mathrm{C}\right)$ waters of deepmarine composition, assuming an ice-free world $\left(\delta^{18} \mathrm{O}_{\text {water }}=\right.$ $-1 \%$ SMOW). Similar isotopic values were obtained for deepmarine equant spar cements in Lower and mid-Cretaceous shallow-bank limestones exposed on the Bahama Escarpment (Freeman-Lynde et al., 1986) and for Campanian-Paleocene hardgrounds recovered from the Caribbean during DSDP Leg 15 

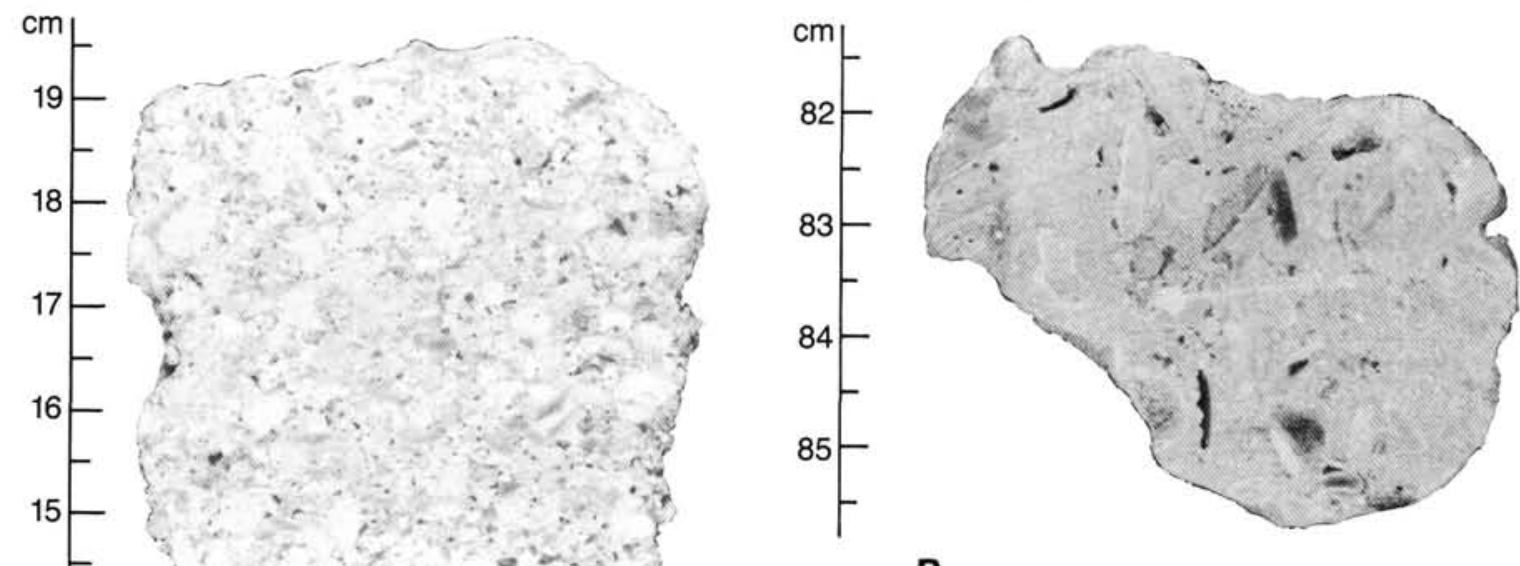

B

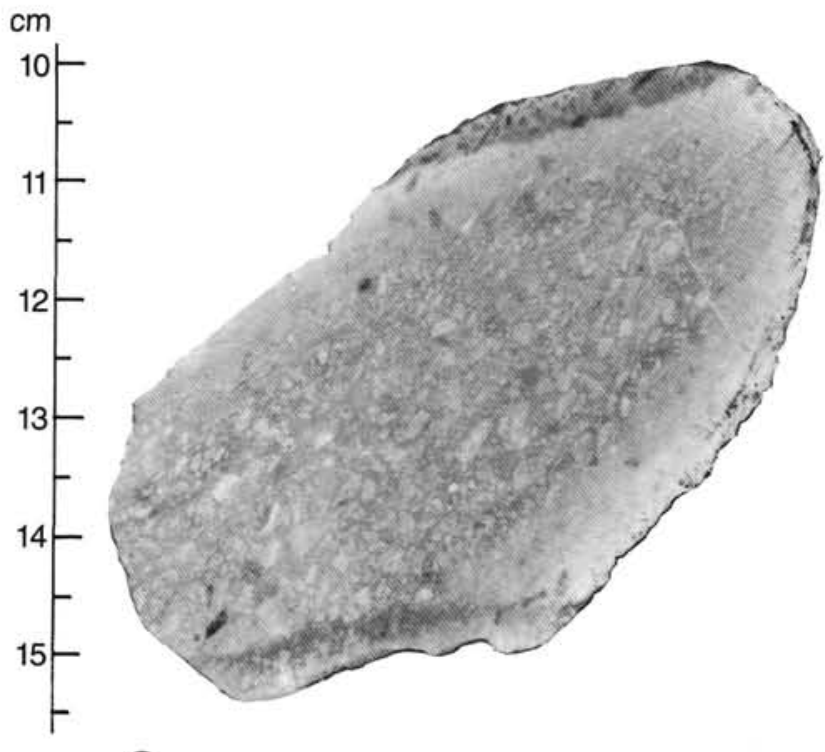

C

Figure 2. Polished slabs illustrating features of Campanian-age sediment gravity-flow deposits in Hole 634A. A. Rudstone composed of shallow-marine skeletal fragments mixed with rip-up clasts of lithified ooze containing planktonic foraminifers. Rip-up clasts indicated by arrows, Sample 101-634A-29R-1, 0-20 cm. B. Rudstone with large (up to $1 \mathrm{~cm}$ ) rounded, poorly sorted skeletal grains and abundant primary interparticle and secondary moldic porosity, Sample 101-634A-28R-1, 81-84 cm. C. Siliceous rudstone with large (up to $5 \mathrm{~mm}$ ) rounded, well-sorted calcite skeletal grains and silica-cemented interparticle porosity, Sample 101-634A-16R, CC, 12-13 cm.

(Anderson and Schneidermann, 1973) (Fig. 6). The $\delta^{18} \mathrm{O}$ values of cements from Hole 634A seem somewhat lighter (heaviest $\delta^{18} \mathrm{O}$ value is $-0.3 \%$ PDB) than those of rip-up clasts (heaviest $\delta^{18} \mathrm{O}$ value is $+0.3 \%$ PDB, Table 4 ) and also appear lighter than values reported for Caribbean hardgrounds (although this field is based on only four analyses). This may reflect secular varia- tion in oxygen isotopic composition of seawater or variation in isotopic fractionation between cement and pelagic sediment, however. Rip-up clasts with heavier $\delta^{18} \mathrm{O}$ values are the oldest samples (Table 3 ), and both rip-up clasts and Caribbean hardgrounds consist of pelagic sediments. Isotopic compositions of equant spar cements (W. Schlager, pers. commun., 1985) in Apt- 

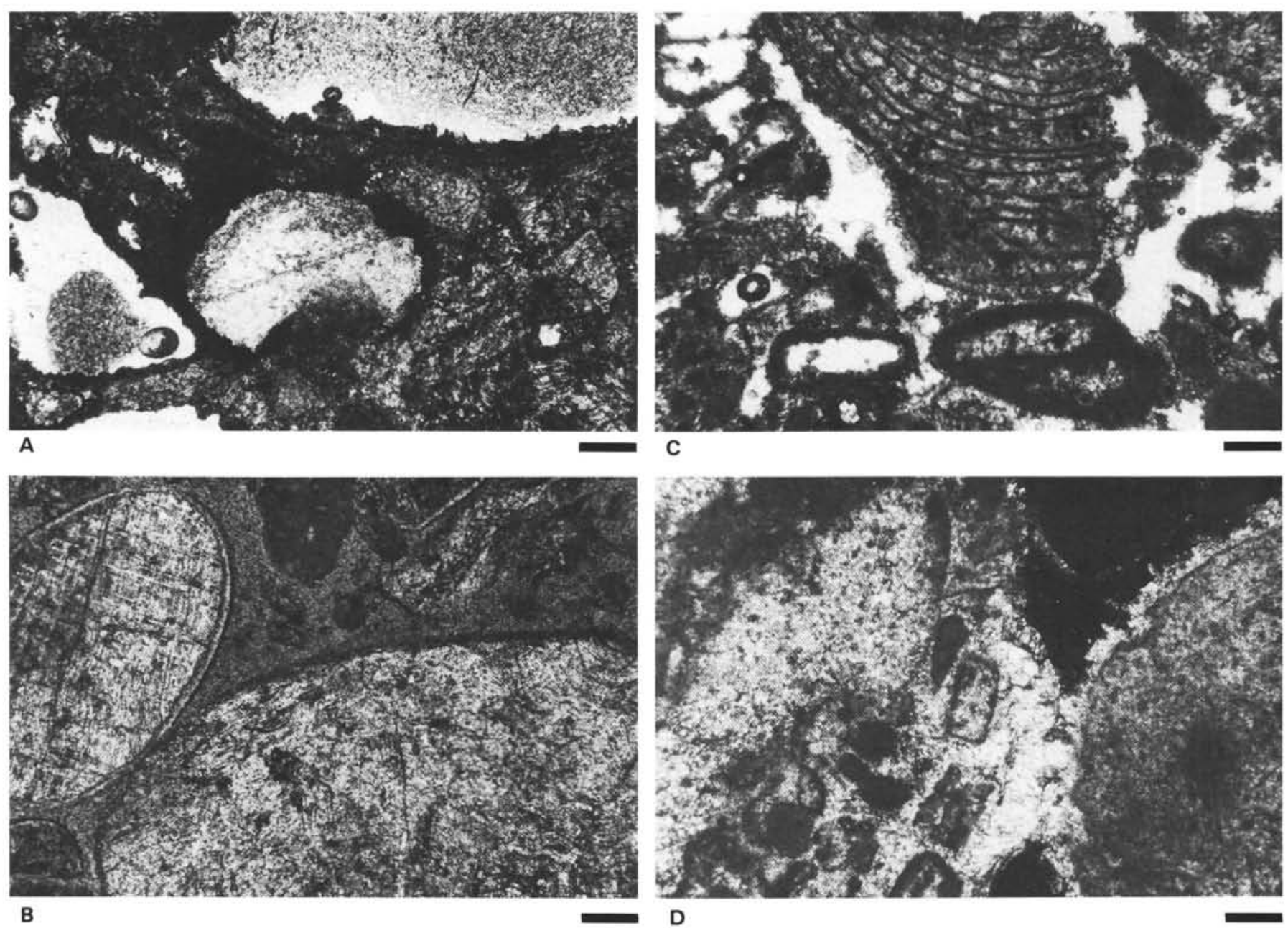

B

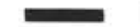

Figure 3. Thin-section photomicrographs illustrating various aspects of Campanian-age sediment gravity-flow grainstones and rudstones recovered from Hole 634A, including shallow-marine skeletal grain characteristics, micrite envelopes, rip-up clasts, porosity types, deep-marine spar, and silicification. Bars represent $200 \mu \mathrm{m}$. A. Moldic porosity surrounded by micrite envelopes, Sample 101-634A-6R-1, 11-13 cm. Note preserved mollusk shell fabric in adjacent skeletal grains. Circles in molds are bubbles in the mounting medium. B. Well-rounded skeletal grains resulting from abrasion in a shallow-marine environment prior to deep-marine deposition, Sample 101-634A-16R, CC, 12-13 cm. Grain at bottom center is a rip-up clast of pelagic slope sediment. Silica fills all interparticle porosity. C. Moldic porosity surrounded by micrite envelopes, and interparticle porosity between skeletal grains with well-preserved algal fabric at top center, Sample 101-634A-26R, CC, 3-4 cm. Note thin rims of deep-marine, very fine to fine, equant spar lining interparticle and intraparticle porosity. D. Very fine to fine, equant spar filling interparticle porosity between skeletal grains with well-preserved mollusk shell fabric, Sample 101-634A-28R-1, 81-84 cm. Figure 4 (A and B) shows SEM photomicrograph enlargements of the same sample.

ian-Albian talus deposits recovered at the base of Campeche Escarpment during DSDP Leg 77 (Halley et al., 1984) also overlap those determined in this study for deep-marine components in Campanian grainstones and rudstones recovered at Hole $634 \mathrm{~A}$ (Fig. 6).

\section{DISCUSSION}

Grainstones and rudstones recovered at Hole 634A contain perireef and periplatform debris that formed in a shallow-marine environment but that accumulated in the deep Northeast Providence Channel after downslope transport by gravity flows during the Late Cretaceous. Diagenesis of this debris began in the shallow-marine environment. Shallow-marine diagenesis is represented by micrite envelopes around biogenic particles in the grainstones and rudstones and by cloudy isopachous, radiaxial fibrous cements, as well as micrite rims, in boundstone lithoclasts (Bathurst, 1975; Longman, 1980).
Lithification of gravity-flow deposits occurred only after the loose sediment reached deep water. Lithification was essentially limited to these gravity-flow deposits; interbedded periplatform ooze remains mostly uncemented or poorly cemented. The source of carbonate ions for cementation during lithification appears to have been dissolution of aragonite and high-magnesium calcite skeletal grains that made up a portion of the transported sediment.

Dissolution resulted from immersion of gravity-flow sediments in colder $\left(10^{\circ}-20^{\circ} \mathrm{C}\right)$, undersaturated waters of the deepmarine environment, probably at the seafloor (Schlager and James, 1978) or after shallow burial (Mullins et al., 1980), as has occurred on the deep slopes of the modern Bahamas. The calcite compensation depth (CCD) was shallow (3000-3500 m) during the Campanian (van Andel, 1975), and the aragonite compensation depth (ACD) probably would have been $1-2 \mathrm{~km}$ shallower than the CCD (1000-2500 m) (Broecker and Peng, 


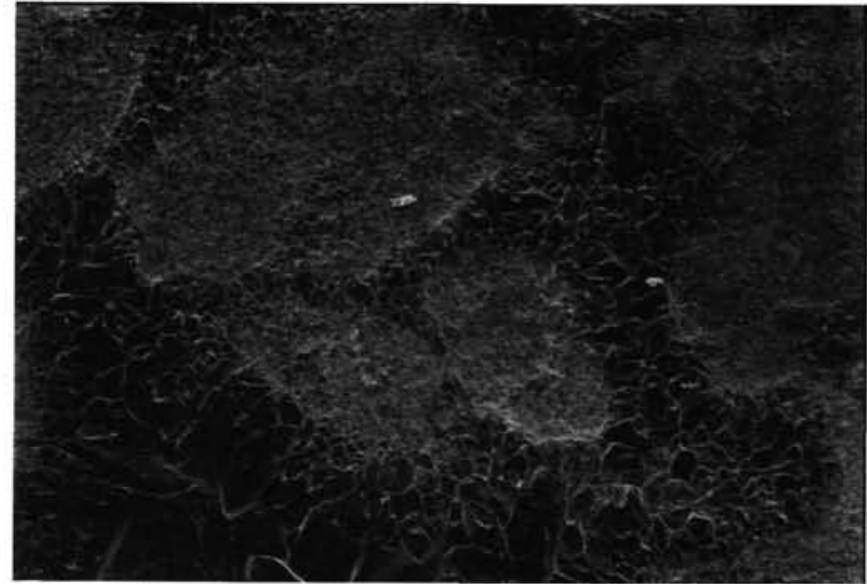

A

$100 \mu \mathrm{m}$

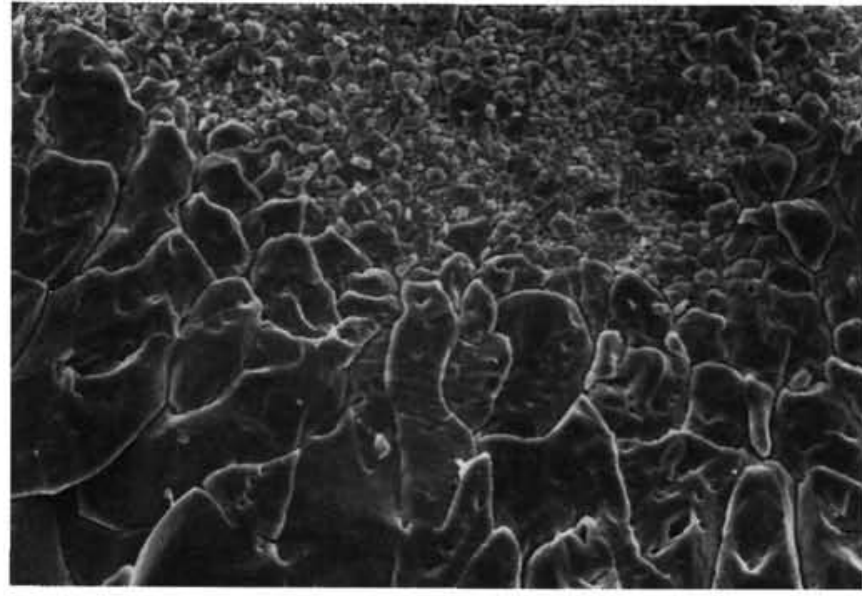

$100 \mu \mathrm{m}$

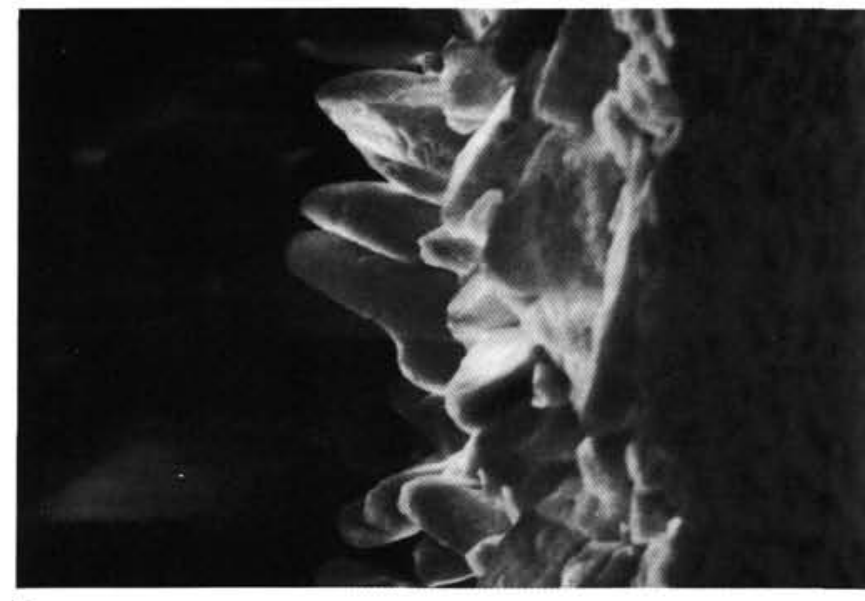

C

$10 \mu \mathrm{m}$

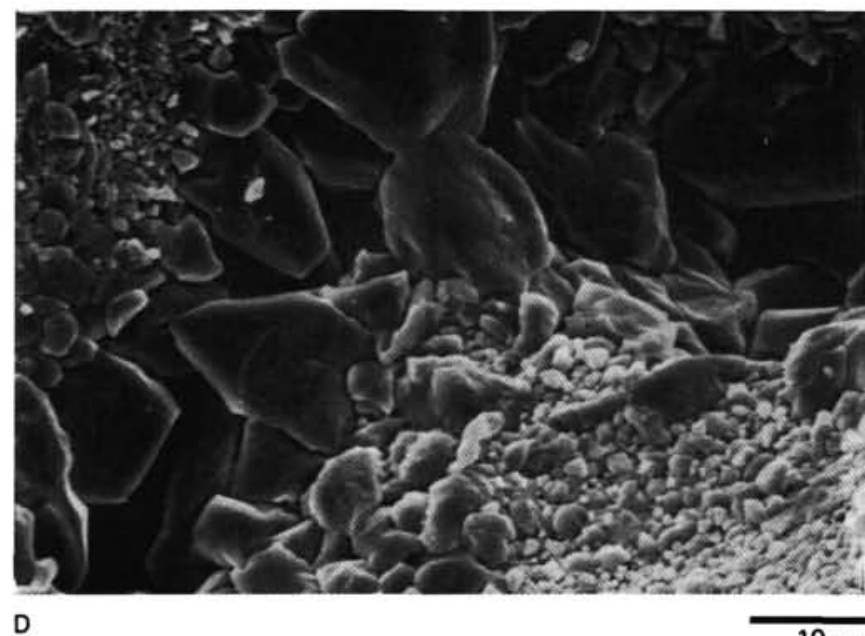

$10 \mu \mathrm{m}$

Figure 4. SEM photomicrographs illustrating deep-marine, cloudy, very fine to fine, and clear fine, equant spar cement in Campanian-age sediment gravity-flow grainstones and rudstones recovered from Hole 634A. A. Small skeletal grains with very fine to fine, equant spar cement filling interparticle porosity, Sample 101-634A-28R-1, 81-84 cm. B. Enlargement of (A) above showing detail of very fine to fine, equant spar. C. Blocky crystalline form of deep-marine spar lining walls of vuggy porosity, Sample 101-634A-6R-1, 11-13 cm. D. Porosity filled with blocky spar crystals growing from opposite walls of small cavity, Sample 101-634A-25R, CC, 18-21 cm.

1982). Campanian sediments recovered at Hole 634A were deposited at about $2 \mathrm{~km}$ water depth (Paulus, 1972; FreemanLynde and Ryan, 1987), and so most likely were beneath the ACD. Even if the ACD were deeper, dissolution of aragonite probably would have occurred in the aragonite lysocline.

Dissolution of the more soluble aragonite and high-magnesium calcite skeletal grains provided an increased carbonate ion concentration in pore fluids that was sufficient to allow precipitation of calcite spar cement in both newly developed moldic porosity and in original depositional pores. It is possible that not all dissolved carbonate was used in the formation of cement, however, as evidenced by thin layers of cement and much unfilled primary and secondary porosity. Rather, some carbonate was required to oversaturate pore fluids. Interbedded periplatform ooze, which presumably contained significant amounts of aragonite and high-magnesium calcite, has not been cemented or has been poorly cemented. The only readily apparent explanation of this lack, or poor development, of lithification is that the permeability of periplatform ooze was less than that of gravity-flow deposits.
Deep-marine cementation most likely occurred at the seafloor or in the shallow subsurface very soon after deposition of the gravity-flow deposits. Presence of lithified layers in an otherwise uncemented sequence is suggestive of hardground formation that occurs at the seafloor (Schlager and James, 1978) or after shallow burial (Mullins et al., 1980).

Our $\delta^{18} \mathrm{O}$ values suggest that equant spar cements probably precipitated from waters of deep-marine composition, not mixed or meteoric composition. Differences in stable oxygen isotopic values between shallow- and deep-marine components most likely reflect temperature differences between shallow- and deep-marine waters during the Campanian. Heavier $\delta^{18} \mathrm{O}$ values of deepmarine components, relative to those of shallow-marine skeletal grains, mostly reflect the colder temperatures $\left(10^{\circ}-20^{\circ} \mathrm{C}\right)$ of deep-marine waters relative to those $\left(20^{\circ}-30^{\circ} \mathrm{C}\right)$ of shallow-marine waters, assuming that both components precipitated in equilibrium with water having a $\delta^{18} \mathrm{O}$ composition of $-1 \%$ SMOW. Similar differences in temperature between deep- and shallowmarine waters were obtained by Savin (1977) for the Late Cretaceous based on $\delta^{18} \mathrm{O}$ compositions of planktonic and benthic 


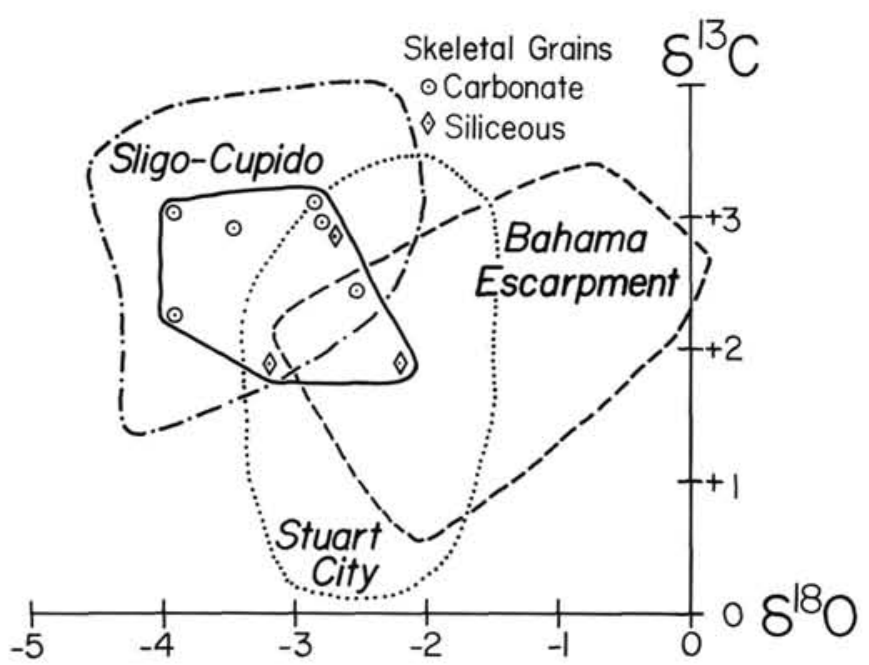

Figure 5. Stable oxygen and carbon isotope compositions of shallowmarine rudist and other mollusk skeletal grains in Campanian-age sediment gravity-flow grainstones and rudstones recovered from Hole 634A (solid line). Dashed and dotted lines indicate isotopic compositions determined for shallow-marine components (micrite and cloudy, fine to coarse, isopachous, radiaxial fibrous calcite) in shallow-water limestones of Early and mid-Cretaceous age exposed on the Bahama Escarpment (Freeman-Lynde et al., 1986), for shallow-marine rudist grains in Lower Cretaceous Sligo and Cupido formations, East Texas subsurface (Moldovanyi and Lohmann, 1984), and for shallow-marine cements in Stuart City Trend strata (Prezbindowski, 1985).

foraminifers. Brass et al. (1982) suggested that warm deep water formed by evaporation of seawater in tropical marginal seas during the Late Cretaceous.

Another possibility explaining the difference in $\delta^{18} \mathrm{O}$ values between rudist skeletal grains and the cements could be that rudists reflect a strong "vital" fractionation. However, Moldovanyi and Lohmann (1984) demonstrated that in the Lower Cretaceous Sligo and Cupido formations rudists exhibit the same isotopic composition as micrite and shallow-marine cements. Thus, it seems unlikely that the "vital" effect accounts for the heavier $\delta^{18} \mathrm{O}$ of the cements.

Crystal form (equant calcite spar), lack of appreciable magnesium, and higher $\delta^{18} \mathrm{O}$ values might indicate cement precipitation in our samples from water with mixed or meteoric composition (Folk and Land, 1975). Generally, however, cements precipitated from meteoric or mixed-zone water are depleted in $\delta^{18} \mathrm{O}$ relative to shallow-marine components (Moldovanyi and Lohmann, 1984; Meyers and Lohmann, 1985). However, if the $\delta^{18} \mathrm{O}$ of the water were depleted by more than $2 \%$ SMOW $\left(\delta^{18} \mathrm{O}_{\text {water }}<-3 \%\right.$ SMOW $)$, then the indicated spar tempera- tures would be implausibly cold $\left(<10^{\circ} \mathrm{C}\right)$. Halley et al. (1984) point out, however, that tropical coastal meteoric waters can be similar to adjacent shallow-marine water with respect to $\delta^{18} \mathrm{O}$. Water of similar isotopic composition to shallow-marine water ( $-1 \%$ SMOW) would give plausible temperatures. Halley et al. (1984) also point out the difficulty of getting meteoric or mixed water to the deep-marine environment ( $\sim 1700 \mathrm{~m}$ water depth) in which their samples were deposited. Our samples were also deposited at similar water depths. Lloyd (1966) indicates that $\delta^{18} \mathrm{O}$ of fresh water along humid tropical coasts can reach $+6.0 \%$ SMOW with excess evaporation. Because the difference in $\delta^{18} \mathrm{O}$ between the shallow- and deep-marine components of this study can be accounted for simply by the temperature difference $\left(10^{\circ} \mathrm{C}\right)$ between those environments, we feel this to be the most logical conclusion.

We suggest that the dissolution occurred in a relatively closed system, because $\delta^{13} \mathrm{C}$ compositions do not vary significantly between shallow- and deep-marine components (Figs. 5 and 6). The $\delta^{13} \mathrm{C}$ values of carbonate cements tend to reflect the isotopic signatures of the source material in closed systems (Allan and Matthews, 1977). Therefore, if dissolving shallow-marine grains supplied the carbonate ions for the cement, the signatures would reflect the same $\delta^{13} \mathrm{C}$ values.

Cement $\delta^{18} \mathrm{O}$ values also may reflect a somewhat lighter isotopic composition for pore fluids from which they precipitated, owing to contribution of isotopically light carbonate supplied by dissolved aragonite and high-magnesium calcite grains. Support for this conclusion is provided by the fact that cement $\delta^{18} \mathrm{O}$ values are slightly lighter than those of deep-marine rip-up clasts in Hole 634A and of DSDP Leg 15 hardgrounds sampled in the Caribbean (Figs. 5 and 6).

The overlap of stable isotope values for deep-marine cements in Campanian gravity-flow deposits in Hole 634A with those for cements in Aptian-Albian talus deposits at the base of Campeche Escarpment at Hole 536 suggests that the latter might also be deep-marine cements. Halley et al. (1984) indicated that isotopic data from Campeche talus components were consistent with a deep-marine origin, although trace-element (particularly $\mathrm{Mg}^{2+}$ ) concentrations were not. Freeman-Lynde et al. (1986) note that trace-element $\left(\mathrm{Sr}^{2+}\right)$ contents were very low (100-200 $\mathrm{ppm}$ ) in Bahama Escarpment cements. These values, lower than would be expected (500-1000 ppm) based on published partition coefficients, were attributed to slower precipitation rates.

\section{SUMMARY}

1. Stable oxygen and carbon isotope values for shallow-marine skeletal grains in Campanian gravity-flow deposits in Hole 634A range between -3.9 and $-2.2 \% 0 \delta^{18} \mathrm{O}$ PDB and +1.90 to $+3.10 \% 0 \delta^{13} \mathrm{C}$ PDB. These $\delta^{18} \mathrm{O}$ values are consistent with precipitation in equilibrium with warm $\left(20^{\circ}-30^{\circ} \mathrm{C}\right)$, shallow-marine waters. These values are similar to those determined for

Table 2. Stable oxygen and carbon isotopic data summary. Values relative to PDB.

\begin{tabular}{|c|c|c|c|c|}
\hline & \multirow{2}{*}{$\begin{array}{c}\text { Shallow marine } \\
\text { Skeletal } \\
\text { grains }\end{array}$} & \multicolumn{3}{|c|}{ Deep marine } \\
\hline & & $\begin{array}{l}\text { Clear medium } \\
\text { equant spar }\end{array}$ & $\begin{array}{l}\text { Cloudy, very } \\
\text { fine to fine } \\
\text { equant spar }\end{array}$ & $\begin{array}{l}\text { Rip-up } \\
\text { clasts }\end{array}$ \\
\hline Number of samples & 9 & 5 & 5 & 3 \\
\hline $\begin{array}{l}\text { Number of micro- } \\
\text { samples }\end{array}$ & 9 & 8 & 5 & 4 \\
\hline$\delta^{18} \mathrm{O} \%_{0}$ range & -2.2 to -3.9 & -0.5 to -2.0 & -0.3 to -1.5 & +0.3 to -1.3 \\
\hline$\delta^{18} \mathrm{O} \%_{0}$ std. dev. & 0.6 & $\begin{array}{r}-1.1 \\
0.6\end{array}$ & 0.4 & 0.6 \\
\hline$\delta^{13} \mathrm{C} \%$ range & +1.9 to +3.1 & +2.3 to +3.6 & +1.7 to +2.7 & +2.0 to +2.6 \\
\hline$\delta^{13} \mathrm{C} \%_{0}$ mean & +2.6 & +3.0 & +2.2 & +2.4 \\
\hline$\delta^{13} \mathrm{C} \%_{0}$ std. dev. & 0.5 & 0.4 & 0.4 & 0.3 \\
\hline
\end{tabular}


Table 3. Stable oxygen and carbon isotopic compositions of shallow-marine components.

\begin{tabular}{clcr}
\hline Sample (interval in cm) & $\begin{array}{c}\text { Component } \\
\text { type }\end{array}$ & $\begin{array}{c}\delta^{18} \mathrm{O} \\
(\% \circ \mathrm{PDB})\end{array}$ & $\begin{array}{c}\delta^{13} \mathrm{C} \\
(\% \circ \mathrm{PDB})\end{array}$ \\
\hline 101-634A-6R-1, 11-13 & Rudist & -3.9 & +2.3 \\
16R, CC, 12-13 & Mollusk & -3.2 & +1.9 \\
25R, CC, 4-8 & Rudist & -2.8 & +3.0 \\
25R, CC, 18-21 & Rudist & -3.9 & +3.0 \\
28R-1, 70-72 & Mollusk & -2.6 & +2.5 \\
28R-1, 81-84 & Rudist & -3.5 & +2.9 \\
28R-1, 90-94 & Rudist & -2.9 & +3.1 \\
29R-1, 51-52 & Rudist & -2.7 & +2.9 \\
29R, CC, 1-3 & Mollusk & -2.2 & +1.9 \\
\hline
\end{tabular}

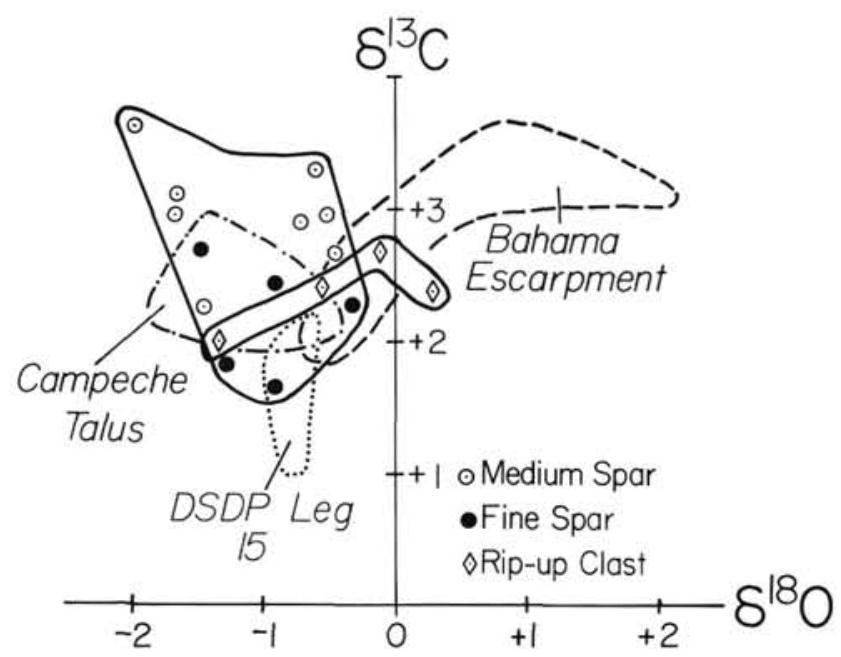

Figure 6. Stable oxygen and carbon isotopic compositions of deep-marine, cloudy, very fine to fine, and clear, medium equant spar cements and deep-marine rip-up clasts in Campanian-age sediment gravity-flow deposits recovered from Hole 634A (solid lines). Dashed and dotted lines indicate isotopic compositions determined for clear, medium to coarse, equant spars (inferred to be Maestrichtian-Tertiary) in shallowwater limestones of Early and mid-Cretaceous age exposed on the Bahama Escarpment (Freeman-Lynde et al., 1986), for Campanian-Paleocene hardgrounds recovered during Leg 15 in the Caribbean (Anderson and Schneidermann, 1973), and for spar cements recovered from Hole 536 from Aptian-Albian talus deposits at the base of Campeche Escarpment (Halley et al., 1984).

Table 4. Stable oxygen and carbon isotopic compositions of deep-marine microsamples.

\begin{tabular}{clcc}
\hline Sample (interval in cm) & $\begin{array}{c}\text { Component } \\
\text { type }\end{array}$ & $\begin{array}{c}\delta^{18} \mathrm{O} \\
\text { (\%o PDB) }\end{array}$ & $\begin{array}{c}\delta^{13} \mathrm{C} \\
(\% 0 \text { PDB })\end{array}$ \\
\hline 101-634A-25R, CC, 4-8 & Medium spar & -2.0 & +3.6 \\
25R, CC, 4-8 & Medium spar & -1.7 & +3.0 \\
25R, CC, 4-8 & Fine spar & -1.5 & +2.7 \\
25R, CC, 18-21 & Medium spar & -0.5 & +3.0 \\
25R, CC, 18-21 & Medium spar & -1.7 & +3.1 \\
27R, CC, 33-34 & Rip-up clast & -1.3 & +2.0 \\
28R-1, 81-84 & Medium spar & -1.5 & +2.2 \\
28R-1, 81-84 & Medium spar & -0.7 & +2.9 \\
28R-1, 81-84 & Fine spar & -0.9 & +1.7 \\
28R-1, 81-84 & Fine spar & -1.3 & +1.9 \\
28R-1, 90-94 & Medium spar & -0.5 & +2.7 \\
28R-1, 90-94 & Fine spar & -0.9 & +2.5 \\
28R-1, 90-94 & Fine spar & -0.3 & +2.3 \\
28R-1, 105-109 & Medium spar & -0.6 & +3.3 \\
31R-1, 33-37 & Rip-up clast & +0.3 & +2.4 \\
31R-1, 38-41 & Rip-up clast & -0.1 & +2.7 \\
31R-1, 38-41 & Rip-up clast & -0.6 & +2.4 \\
\hline & & & \\
\hline
\end{tabular}

other Cretaceous shallow-marine components in the Bahamas and Gulf of Mexico.

2. Stable oxygen and carbon isotope values for deep-marine components (equant spar and rip-up clasts of periplatform ooze) range between -2.0 and $+0.3 \%{ }^{18} \mathrm{O}$ PDB and +1.7 and $+3.6 \% 0 \delta^{13} \mathrm{C}$ PDB. Deep-marine components have heavier ${ }^{18} \mathrm{O}$ values than shallow-marine components, but $\delta^{13} \mathrm{C}$ values are similar. Enrichment in $\delta^{18} \mathrm{O}$ is consistent with precipitation of deep-marine cements in equilibrium with colder $\left(10^{\circ}-20^{\circ} \mathrm{C}\right)$ waters of deep-marine composition. Isotopic compositions of deepmarine components in our samples are similar to values determined in deep-marine components in the Bahamas and Caribbean.

3. The source of carbonate for cementation of sediment gravity-flow deposits appears to have been dissolution of shallowmarine aragonite and high-magnesium calcite skeletal grains within the deposits.

\section{ACKNOWLEDGMENTS}

This study was funded by JOI U.S. Science Advisory Committee through Texas A\&M University Research Foundation (to R. P. FreemanLynde) and by U.S. Office of Naval Research contract N00014-85-K0433 (to the University of Georgia). W. R. McClain acknowledges a grant from the Levy-Grant-in-Aid Fund of the Department of Geology and the University of Georgia. We acknowledge the professionalism of the captain and crew of the JOIDES Resolution and of the ODP scientific and technical staff. We thank D. Detman of the University of Michigan for isotope analyses. This manuscript was critically reviewed by J. A. Austin, Jr., T. Freeman, S. Dorobek, A. A. Palmer, and W. Schlager.

\section{REFERENCES}

Allan, J. R., and Matthews, R. K., 1977. Carbon and oxygen isotopes as diagenetic and stratigraphic tools: Surface and subsurface data, Barbados, West Indies. Geology, 5:16-20.

Anderson, T. F., and Schneidermann, N., 1973. Stable isotope relationships in pelagic limestones from the central Caribbean: Leg 15, Deep Sea Drilling Project. In Edgar, N. T., Saunders, J. B., et al., Init. Repts. DSDP, 15: Washington (U.S. Govt. Printing Office), 795803.

Andrews, J. E., Shepard, F. P., and Hurley, R. J., 1970. Great Bahama Canyon. Geol. Soc. Am. Bull., 81:1061-1078.

Austin, J. A., Jr., Schlager, W., et al., 1986. Proc. ODP, Init. Repts., 101: College Station, TX (Ocean Drilling Program).

Bathurst, R.G.C., 1975. Carbonate Sediments and Their Diagenesis (Developments in Sedimentology 12): Amsterdam (Elsevier).

Brass, G. W., Southam, J. R., and Peterson, W. H., 1982. Warm saline bottom water in the ancient ocean. Nature, 296:620-623.

Broecker, W. S., and Peng, T.-H., 1982. Tracers in the Sea: LamontDoherty Geol. Observ. Publ., Palisades, NY.

Craig, H., 1957. Isotopic standards for carbon and oxygen and correction factors for mass spectrometric analyses of carbon dioxide. Geochim. Cosmochim. Acta, 12:133-149.

Folk, R. L., and Land, L. S., 1975 . Mg/Ca ratio and salinity; two controls over crystallization of dolomite. AAPG Bull., 59:60-68.

Freeman-Lynde, R. P., and Ryan, W.B.F., 1987. Subsidence history of the Bahama Escarpment and the nature of crust underlying the Bahamas: Earth Planet. Sci. Lett., 84:457-470.

Freeman-Lynde, R. P., Whitley, K. F., and Lohmann, K. C., 1986. Deep-marine origin of equant spar cements in Bahama Escarpment limestones. J. Sediment. Petrol., 56:799-811.

Halley, R. B., Pierson, B. J., and Schlager, W., 1984. Alternative diagenetic models for Cretaceous talus deposits, DSDP Site 536, Gulf of Mexico. In Buffler, R. T., Schlager, W., et al., Init. Repts. DSDP, 77: Washington (U.S. Govt. Printing Office), 397-408.

Hook, J. E., Golubic, S., and Milliman, J. D., 1984. Micritic cement in microborings is not necessarily a shallow-water indicator. J. Sediment. Petrol., 54:425-431.

Lloyd, R. M., 1966. Oxygen isotope enrichment of sea water by evaporation. Geochim. Cosmochim. Acta, 30:801-814.

Longman, M. W., 1980. Carbonate diagenetic textures from nearsurface diagenetic environments. AAPG Bull., 64:461-487. 
Meyers, W. J., and Lohmann, K. C., 1985. Isotopic geochemistry of regionally extensive calcite cement zones and marine components in Mississippian limestones, New Mexico. In Schneidermann, N., and Harris, P. M. (Eds.), Carbonate Cements: Soc. Econ. Paleontol. Mineral. Spec. Publ., 36:223-239.

Moldovanyi, E. P., and Lohmann, K. C., 1984. Isotopic and petrographic record of phreatic diagenesis: Lower Cretaceous Sligo and Cupido Formations. J. Sediment. Petrol., 54:972-985.

Moore, C. H., 1985. Upper Jurassic subsurface cements: a case history. In Schneidermann, N., and Harris, P. M. (Eds.), Carbonate Cements: Soc. Econ. Paleontol. Mineral. Spec. Publ., 36:291-308.

Mullins, H. T., and Lynts, G. W., 1977. Origin of the northwestern Bahama Platform: Review and reinterpretation. Geol. Soc. Am. Bull., $88: 1447-1461$.

Mullins, H. T., and Neumann, A. C., 1979. Deep carbonate bank margin structure and sedimentation in the northern Bahamas. In Doyle, L., and Pilkey, O. H. (Eds.), Geology of Continental Slopes: Soc. Econ. Paleontol. Mineral. Spec. Publ., 27:165-192.

Mullins, H. T., Neumann, A. C., Wilber, R. J., and Boardman, M. R., 1980. Nodular carbonate sediment on Bahamian slopes: possible precursors to nodular limestones. J. Sediment. Petrol., 50:117-131.

Paulus, F. J., 1972. The geology of Site 98-Northeast Providence Channel. In Hollister, C. D., Ewing, J. I., et al., Init. Repts. DSDP, 11: Washington (U.S. Govt. Printing Office), 877-897.

Prezbindowski, D. R., 1985. Burial cementation-is it important? A case study, Stuart City Trend, south central Texas. In Schneidermann,
N., and Harris, P. M. (Eds.), Carbonate Cements: Soc. Econ. Paleontol. Mineral. Spec. Publ., 36:241-264.

Savin, S. M., 1977. The history of the earth's surface temperature during the last 100 million years. In Donath, F. A., Stehli, F. G., and Wetherill, G. A. (Eds.), Annu. Rev. Earth Planet. Sci., 5:319-355.

Schlager, W., and Chermak, A., 1979. Sediment facies of platform-basin transition, Tongue of the Ocean, Bahamas. In Doyle, L. J., and Pilkey, O. H. (Eds.), Geology of Continental Slopes: Soc. Econ. Paleontol. Mineral. Spec. Publ., 27:193-208.

Schlager, W., and James, N. P., 1978. Low-magnesian calcite limestones forming at the deep-sea floor, Tongue of the Ocean, Bahamas. Sedimentology, 25:675-702.

Schlager, W., Hooke, R. L., and James, N. P., 1976. Episodic erosion and deposition in the Tongue of the Ocean (Bahamas). Geol. Soc. Am. Bull., 87:1115-1118.

van Andel, Tj. H., 1975. Mesozoic/Cenozoic Calcite Compensation Depth and the global distribution of calcareous sediments. Earth Planet. Sci. Lett., 26:187-195.

Woronick, R. E., and Land, L. S., 1985. Late burial diagenesis, Lower Cretaceous Pearsall and Lower Glen Rose Formations, south Texas. In Schneidermann, N., and Harris, P. M. (Eds.), Carbonate Cements: Soc. Econ. Paleontol. Mineral. Spec. Publ., 36:265-275.

Date of initial receipt: 12 December 1986

Date of acceptance: 25 September 1987 Ms 101B-138 